\title{
The Political Economy of the British National Health Service, 1945-1975: Opportunities and Constraints?
}

\author{
JOHN STEWART*
}

The National Health Service (NHS) has often been regarded, by both academic commentators and the public, as the centrepiece of Britain's welfare state. It has retained a high degree of popularity, and politicians have had to take account of this, privately and publicly. So, for example, in the late 1950s a leading Conservative observed that the electorate might accept cuts in defence spending: "But meddle with National Health? That's political suicide."1 A quarter of a century later Margaret Thatcher felt obliged to declare at the Conservative Party annual conference that "the National Health Service is safe with us". 2 The Labour Party has been particularly keen to associate itself with the NHS, playing on its central role in the service's creation. At the 2001 general election, for instance, the manifesto of the Scottish Labour Party proclaimed that: "For over 50 years, the NHS has been part and parcel of what it means to be British. Its foundations-tax-based funding and care according to need-remain as valid today as ever." 3 In doing so, it stressed the service's founding principles alongside the assertion that it is a central component of British identity.

The purpose of this essay is to set the scene for the other pieces in this collection by looking first at the opportunities afforded by the creation of the National Health Service; and, second and in rather more detail, at the constraints upon it. This is not to decry the service's undoubted achievements. Rather, it is to argue that as a result of factors both intended and unintended brakes have been put on the development of the kind of unified health service, dedicated to preventive and social medicine, that reformers have envisaged since the beginning of the twentieth century. The achievements of the NHS notwithstanding, there is a large measure of truth in the observations of some early critics who argued that what was created was not a national health service at all. Instead, it was a national hospital or a national sickness service - that is one which focused largely on hospital and curative medicine, and did little actively to promote health. ${ }^{4}$

(C) John Stewart 2008

*Professor John Stewart, School of Law \& Social Sciences, Glasgow Caledonian University, Cowcaddens Road, Glasgow G4 0BA, UK.

\footnotetext{
${ }^{1}$ Quoted in Charles Webster, The health services since the war: Volume 1: Problems of health care, London, HMSO, 1988, p. 390.
}

\footnotetext{
${ }^{2}$ Quoted in Charles Webster, The National Health Service: a political history, 2nd ed., Oxford University Press, 2002, p. 147.

${ }^{3}$ Scottish Labour Party, Ambitions for Scotland, Glasgow, Scottish Labour Party, 2001.

${ }^{4}$ On such criticisms from the political left, and from a previously influential group in Labour Party health policy, see John Stewart, 'The battle for health': a political history of the Socialist Medical Association, 1930-51, Aldershot, Ashgate, 1999.
} 


\section{John Stewart}

In consequence, overlapping or related areas such as public health, preventive medicine, and social medicine were relatively neglected. ${ }^{5}$

This essay also incorporates a brief case study of the Medical Research Council (MRC). The aim here is twofold: to show, using a particular example, how opportunities and constraints operated in practice in an era of (purportedly) socialized medicine. Second, to provide further background for the papers by Helen Valier and Carsten Timmermann, and by Luc Berlivet. The former examines an important aspect of the MRC's work, clinical trials. ${ }^{6}$ As we shall see, the Council sought to encourage medical research across a wide spectrum-from "pure" science to social medicine. Such a broad definition of medical research, and the range of solutions offered for the problems diagnosed, reflected the range of scientific and policy options available in the post-war era. Berlivet's paper, meanwhile, deals with a body which in certain key respects was the French equivalent of the MRC - the Institut National d'Hygiène (INH, which in 1964 became the Institut National de la Santé et de la Recherche Médicale, INSERM). ${ }^{7}$ Both bodies had broad remits within the general field of promoting medical research. Moreover, the very existence of INSERM owed much to the MRC model. ${ }^{8}$ The respective accounts of their functions and activities thus allows for the sort of comparisons encouraged and stimulated by this collection. As with other papers in this volume, the period covered by this essay is from the end of the Second World War to the early 1970s - the era of the "classic" welfare state. This in turn coincided with what has been termed the "era of biomedicine", in which the MRC played an important part.

\section{The MRC and its Definition of Medical Research}

As Anne Hardy has remarked, the MRC has received relatively little attention from historians. ${ }^{9}$ But in principle at least it had an important strategic and commissioning role in medical research and, by the early 1970s, was receiving around $£ 25$ million

\footnotetext{
${ }^{5}$ On social medicine, see, for example, Dorothy Porter, 'The decline of social medicine in Britain in the 1960s', in Dorothy Porter (ed.), Social medicine and medical sociology in the twentieth century, Amsterdam, Rodopi, 1997, pp. 97-119.

${ }^{6}$ Helen Valier and Carsten Timmermann, 'Clinical trials and the reorganization of medical research in post-Second World War Britain', below.

${ }^{7}$ Luc Berlivet, 'Between expertise and biomedicine: public health research in France after the Second World War', below.

${ }^{8}$ See Viviane Quirke, Collaboration in the pharmaceutical industry: changing relationships in Britain and France, 1935-1965, New York and Abingdon, Routledge, 2007, ch. 5 and 6.

${ }^{9}$ Anne Hardy, Health and medicine in Britain since 1860, Basingstoke, Palgrave, 2001, p. 100. For an "official" history of the MRC, see A Landsborough Thomson, Half a century of medical
}

research. Volume 1: Origins and policy of the Medical Research Council, and Half a century of medical research. Volume 2: The programme of the Medical Research Council, London, HMSO, 1973; and, more briefly, A Landsborough Thomson, 'Origin and development of the Medical Research Council', Br. med. J., 1963, ii: 1290-92. For a collection of essays on the MRC which deal for the most part with the first half of the twentieth century, see Joan Austoker and Linda Bryder (eds), Historical perspectives on the role of the MRC, Oxford University Press, 1989. An important aspect of the Council's role in the first half of the twentieth century is discussed in Edward Higgs, 'Medical statistics, patronage and the state: the development of the MRC Statistical Unit, 1911-1948', Med. Hist., 2000, 44 (3): 323-40. For the influence of this Unit on INSERM, see Berlivet, 'Between expertise and biomedicine', below. 
pounds from the government. ${ }^{10}$ The MRC was founded in 1913 with a brief, as its "official" historian-Sir Arthur Landsborough Thomson-put it, to "promote research in the biomedical field". From the outset it was, and remained, an independent body in the sense that it was not attached to any particular government ministry. Rather, it was under the control of, first, a committee of the Privy Council and then, from the mid1960s, the Department for Education and Science. ${ }^{11}$ This autonomy was to ensure that the Council be "a scientific body of independent standing" and that it likewise should not be subject to "the pressures inseparable from attachment to a large administrative department"- namely, the Ministry of Health. None the less, the Ministry, along with other government departments and bodies with an interest in health issues, was represented on the Council. Equally, the overwhelming majority of its members were appointed for their expertise in medical science. ${ }^{12}$ This situation was confirmed by the National Health Service Acts of the late 1940s. The actual mechanisms varied over time, but essentially the MRC was directly funded by the central state. ${ }^{13}$

In terms of the research it undertook or promoted, the MRC took a broad view. Shortly after the creation of the NHS, James Stirling Ross remarked that the Council had "power ... to promote a programme of research on the widest lines ... particularly for long-range problems". ${ }^{14}$ Its official historian claimed that "the whole of medical science has always been the Council's field". Although the particular emphasis changed over time, none the less the MRC's origins lay in preventive medicine. It had, for instance, taken an interest in "industrial and social medicine" as a result of the problems experienced by munitions workers during the First World War. The Public Health Laboratory Service, which was under the control of the MRC until its own independence in 1961, was an important instance of this approach. ${ }^{15}$ The Council further involved itself in social medicine and health inequalities by, for example, supporting the Social Medicine Research Unit from its foundation in the late 1940s until its demise in 1975. As Shaun Murphy has noted, the Unit was set up when enthusiasm for social medicine, "generated by an upsurge in interest in social issues and a specific desire to promote occupational health research", was high. ${ }^{16}$ Among the issues the Unit investigated were, in the early 1950s, the incidence of coronary heart disease in certain occupations; and, in the mid-1960s, juvenile delinquency in East London. ${ }^{17}$ Mental health and its social context, meanwhile, were dealt with by the Social Psychiatry Research Unit

\footnotetext{
${ }^{10}$ Parliamentary Debates, 5th Series, vol. 874 cols. 457-8, Written Answers, 10 June 1974.

${ }^{11}$ Landsborough Thomson, Half a century of medical research. Volume 1, op. cit., note 9 above, pp. v, 47, 61. The MRC was originally the Medical Research Committee. Its name was changed at the time of the creation of the Ministry of Health immediately after the First World War.

${ }^{12}$ Landsborough Thomson, 'Origin and development', op. cit., note 9 above, pp. 1291-92.

${ }^{13}$ Landsborough Thomson, Half a century of medical research. Volume 1, op. cit., note 9 above, ch. 15 .
}

\footnotetext{
${ }^{14}$ James Stirling Ross, The National Health Service in Great Britain, Oxford University Press, 1952, p. 167.

${ }^{15}$ Landsborough Thomson, 'Origin and development', op. cit., note 9 above, p. 1292.

${ }^{16}$ Shaun Murphy, 'The early days of the MRC Social Medicine Research Unit', Soc. Hist. Med., 1999, 12 (3), pp. 389-406, at p. 405.

${ }^{17}$ Report of the Medical Research Council for the Year 1950-1951, Cmd. 85841, London, HMSO, 1952, p. 85; Report of the Medical Research Council, October 1963-March 1965, Cmnd. 2787, London, HMSO, 1965, p. 153.
} 


\section{John Stewart}

which in the late 1950s was investigating, inter alia, admission patterns to London mental hospitals. ${ }^{18}$

Nor was clinical research neglected. The appointment of Professor Harold Himsworth as Secretary of the MRC in 1949 gave a particular boost to the Council's activities in this field. ${ }^{19}$ The Council itself noted in the early 1950s that "during the present century progress in medical research has been more rapid than at any other time in history". Historically, though, clinical research had been slower to make advances but in recent decades "progress in the clinical field has been gaining momentum". This had come about because of the increasing possibility of direct investigation on patients. Advances in clinical knowledge were thus "no longer dependent entirely upon the chance observation of naturally occurring events", so allowing for a truly "scientific" approach. $^{20}$

But the MRC consciously and explicitly embraced a very broad definition of "clinical research". Dealing with this subject in the context of the formation of the NHS, a 1953 Council document noted that it used

the term "clinical research" to imply research into the mechanisms and causation of disease, including its prevention and cure. Thus, in the sense in which we use the term, it covers not simply work on patients in hospital but also field studies in epidemiology and social medicine and observations in general practice. We wish it to be clearly understood that this interpretation applies throughout the document [my emphasis].

The "essential reason" for such a push for clinical research was, the report continued, "that the growth of scientific knowledge has now progressed to the stage at which clinical research can be developed, with confidence, on a scale commensurate with the need". Consequently the MRC, under the guidance of a newly created Clinical Research Board, was to have the financial responsibility for research in the health services. One further, and important, feature of this scheme was that provision be made for a certain volume of research to be locally initiated. ${ }^{21}$ The aim here was clearly to involve local hospitals, universities, and various medical practitioners in medical research.

As we shall see, this proved to be rather more problematic than it at first appeared. None the less, in the early 1950s at least there was clearly an optimism about what scientific research in medicine, broadly defined, could achieve and this parallels the optimism about the changes brought about by the creation of the NHS. It is therefore appropriate now to examine in more detail the opportunities afforded to the NHS and the MRC by the post-war settlement.

${ }^{18}$ Report of the Medical Research Council for the Year 1959-1960, Cmnd. 1422, London, HMSO, 1961, p. 131.

${ }^{19}$ Christopher Booth, 'Clinical research', in Austoker and Bryder (eds), op. cit., note 9 above, pp. 205-41, at p. 232ff; Valier and Timmermann, 'Clinical trials and the reorganization of medical research in post-Second World War Britain', below.

\footnotetext{
${ }^{20}$ Report of the Medical Research Council for the
} Year 1951-1952, Cmd. 8876, London, HMSO, 1953, pp. 3-4.

${ }^{21}$ Medical Research Council, Ministry of Health, and the Department of Health for Scotland, Clinical research in relation to the National Health Service, London,

HMSO, 1953, pp. 5, 21. See also Valier and Timmermann, 'Clinical trials and the reorganization of medical research in post-Second World War Britain', below. 


\section{Opportunities}

The era from around the mid-1940s to around the mid-1970s was, it is often argued, the era of the "classic" welfare state founded on the Keynes-Beveridge paradigm; and, as such, a period of both economic growth and welfare state creation, consolidation, and expansion. The thirty years or so after the end of the Second World War contrasted with the devastation of the war itself and the social misery and health inequalities of the era which preceded it. Similarly, the "golden age" of post-war welfare capitalism can also be contrasted with the socio-economic and political upheavals which started in the 1970 s and resulted in, inter alia, a fundamental questioning of the premises of statesponsored social welfare throughout the western world. The age of "consensus", during which both major British political parties roughly agreed on the need for a welfare state and a managed economy, ended, so the argument goes, as a result of both external pressures and its own internal contradictions and inefficiencies.

If we look specifically at the NHS, it is clear that the fundamental principles on which it was based-comprehensive health care free at the point of consumption for all citizensinstituted a radically different way of financing and distributing health care. $^{22}$ Previously, access to health care had been determined by factors such as income, participation in insurance schemes, age, gender, class, and geographical location. Unlike post-war health care systems in other parts of western Europe, Britain's was funded not by social insurance but out of general taxation, of itself a form of social solidarity wherein costs as well as benefits were universalized. While I shall have to qualify this later, in broad terms the NHS and its founding principles remained largely unaltered at least until the 1980s.

As might therefore be expected, since its creation the NHS has consumed a more or less continuously rising proportion of the nation's resources. This growth in health expenditure, although again this will have to be qualified, was ahead of the rate of growth of the economy as a whole. ${ }^{23}$ Equally, we can see that the growth of NHS spending occurred irrespective of which political party was in power. Even though health expenditure has been a highly problematic area, it can quite reasonably be pointed out that one part of the service's "success" was the huge amount of money which from the very beginning had to be devoted to curing the accumulated ills of the British people. This was not a negative characteristic of the service for its supporters-on the contrary. The fact that not only did so many people need to be treated, but also that they indeed were, showed that the system worked and the money was worth spending. Such an argument was put forward at the outset by the minister responsible for the creation of the NHS, Aneurin Bevan, although he was not unreservedly against the possibility of imposing charges in certain areas. ${ }^{24}$

While clearly other factors were involved, in terms of health outcomes, the era of the NHS has seen a steady improvement in the health of the British population. So, for

\footnotetext{
${ }^{22}$ For recent work on the history of health care financing, see Martin Gorsky and Sally Sheard (eds), Financing medicine: the British experience since 1750, London, Routledge, 2006.
}

\footnotetext{
${ }^{23}$ See R C O Matthews, C H Feinstein, and J C Odling-Smee, British economic growth, 1856-1973, Oxford, Clarendon, 1982, p. 25 Table 2.3, and passim.

${ }^{24}$ Webster, op. cit., note 1 above, p. $143 \mathrm{ff}$.
} 


\section{John Stewart}

Table 1

Health expenditure, 1946-1976

\begin{tabular}{llllll}
\hline & 1946 & 1951 & 1961 & 1971 & 1976 \\
\hline Health expenditure as \% of GDP & 1.72 & 3.46 & 3.28 & 4.02 & 4.91 \\
Health expenditure, $£$ billion, at $1995 / 6$ prices & 3.5 & 8.6 & 10.9 & 17.5 & 23.7
\end{tabular}

Derived from Tables 2A.1 and 2A.2 in Howard Glennerster, 'New beginnings and old continuities', in Howard Glennerster and John Hills (eds), The state of welfare: the economics of social spending, 2nd ed., Oxford University Press, 1998, pp. 12-26, at pp. 25-6.

Table 2

NHS expenditure, percentage growth per annum by political complexion of government

\begin{tabular}{|c|c|c|c|c|c|}
\hline 1951-55 Cons & 1955-59 Cons & 1959-64 Cons & 1964-70 Lab & 1970-74 Cons & 1974-79 Lab \\
\hline 1.1 & 2.1 & 3.5 & 3.2 & 3.1 & 2.3 \\
\hline
\end{tabular}

Derived from Figure 4.2 in Judith Allsop, Health policy and the NHS: towards 2000, 2nd ed., Harlow, Longman, 1995, p. 69.

instance, life expectancy at birth has risen steadily for both men and women and the mortality rate for one especially vulnerable group, the very young, has declined sharply. ${ }^{25}$ Perhaps more intangibly, but importantly, none the less, for the British people as a whole, the "fear" of falling sick has, at least from an economic point of view, been removed. It is worth bearing in mind that Bevan's political testament was entitled In place of fear ${ }^{26}$ Bevan viewed the NHS itself as "pure socialism", and the idea of removing "fear" in the provision of health care was especially appropriate given the circumstances under which it had previously been given and received. Equality of access, irrespective of any constraining factor including income, had in other words been guaranteed by the NHS settlement.

The post-1945 era also saw huge advances in medical knowledge, science, and technology; and in attitudes to medical research. The MRC played an active and important part in that respect. In a Commons debate in 1950 on the use of scientific resources, one MP described the Council as a "particularly successful example of administration and organisation". 27 Two years later the MRC conducted research into what at first might appear a rather esoteric area of social concern-the employment problems experienced

\footnotetext{
${ }^{25}$ Judith Allsop, Health policy and the NHS: towards 2000, 2nd ed., Harlow, Longman, 1995, pp. 120-1, Figure 6.1; Hardy, op. cit., note 9 above, p. 180 , Table 1.

${ }^{26}$ On In place of fear, see, for example, the essays in Geoffrey Goodman (ed.), The state of the nation:
}

the political legacy of Aneurin Bevan, London, Victor Gollancz, 1997.

${ }^{27}$ Parliamentary Debates, 5th Series, vol. 474, col. 2096, Group-Captain Wilcock, 1950. 
by disabled youths in Glasgow. But, the Council report noted, there could be "few more promising fields for the practice of constructive medicine". Consequently, the report's recommendations embraced both the "overriding need to improve basic living conditions" and "to harness all the resources of medicine for the prevention of disease". ${ }^{28}$ In a more obviously clinical field, meanwhile, the MRC consciously moved into the area of cancer research. This had previously been the domain of the Imperial Cancer Research Fund and the British Empire Cancer Campaign, and the MRC's move, as Timmermann has suggested, was part of its strategy to establish itself as "the main body controlling clinical research in Britain". ${ }^{29}$

Reflecting on the MRC's role in relation to "pure" medical science, Sir George Pickering, Regius Professor of Medicine at the University of Oxford, addressed the dinner celebrating the MRC's fiftieth anniversary. The Council had, Pickering claimed, "with great wisdom not restricted the quest for new knowledge to a narrow field". As a "spectacular and thrilling" example of this approach he cited the MRC-sponsored research on the structure of proteins. This was, he exclaimed, "[A] far cry from practical medicine! But then", Pickering continued, "so are the new synthetic penicillins from the culture fluid which grew the mould." The Council had assumed the role of patron of "novel and venturesome scientific research" and its own institution, the National Institute for Medical Research, was "one of the most brilliant centres of medical research in the world, and cradle of some of the most distinguished scientists". 30

All this was underpinned by steadily rising financial support from government. MRC income rose from just under half a million pounds in the immediate post-war period to, as we have seen, around $£ 25$ million by the early 1970s. Even adjusted for inflation, which was running at relatively low rates in the 1950s and 1960s, this was a significant increase. Landsborough Thomson calculated that between the early 1950s and late 1960s there was a cumulative annual growth rate of just under 10 per cent. ${ }^{31}$ This too is impressive, especially when placed against the rates of health expenditure and economic growth discussed above. And, while the principal source of the MRC's income was direct government aid, it also received financial support from elsewhere. In 1965, for instance, other government departments, and most notably the Ministry of Health, contributed over half a million pounds. Further support came from charitable foundations, usually for specific purposes or pieces of research. Large-scale donors included the Rockefeller Foundation and the Wellcome Trust, each giving over $£ 20,000$ for travelling fellowships. ${ }^{32}$

There are, then, good reasons to take an optimistic view of Britain's health services and medical research in the era of the "classic" welfare state. There were also, however,

\footnotetext{
${ }^{28}$ T Ferguson, A N Macphail, and Margaret I McVean, Employment problems of disabled youth in Glasgow, Medical Research Council: Memorandum 28, London, HMSO, 1952, pp. 1, 65.

${ }^{29}$ Carsten Timmermann, 'As depressing as it was predictable? Lung cancer, clinical trials, and the Medical Research Council in postwar Britain', Bull. Hist. Med., 2007, 81 (1): 312-34, at p. 318.
}

\footnotetext{
${ }^{30}$ Sir George Pickering, 'The future of the Medical Research Council', Br. med. J, 1963, ii: 1293-94, at p. 1293.

${ }^{31}$ Landsborough Thomson, Half a century of medical research. Volume 1, op. cit., note 9 above, p. 204.

${ }^{32}$ Report of the Medical Research Council, October 1963-March 1965, Cmnd. 2787, London, HMSO, 1965, pp. 280, 283.
} 


\section{John Stewart}

constraints. I now examine these under three broad categories-expenditure, structure and attitudes, and the wider context, before once again focusing briefly on the MRC case study.

\section{Constraints: Expenditure}

To start, then, with the complex question of funding. Jim Tomlinson has argued that what was created in Britain in the 1940s was an "austere" welfare state. To take one measure of this, by the early 1950s in a league table of European public expenditure Britain occupied mid-position lagging behind, most notably, West Germany. More specifically on the NHS, Tomlinson has pointed out that no new hospitals were built until the 1960s; and that health centres, which had been promised by the 1946 Act, barely took off at all. ${ }^{33}$ Indeed health centres provide a useful example of how certain aspects of what had been envisaged of the NHS did not come to pass. The idea behind them was that these small, community-based institutions would provide facilities for all aspects of primary care. General practitioners would work alongside, and in co-operation with, other health workers such as dentists, health visitors, and specialists in child medicine. This integrated approach would thus embrace not only curative medicine but also, and crucially, preventive and social medicine. The "failure" of health centres was certainly due in part to material shortages in the immediate post-war period, but it was also the result of the attitude of the medical profession, an issue to which I will return. ${ }^{34}$

The apparently optimistic picture painted by the broad-brush Table 1 above, with its secular upward trend of expenditure, also has to be qualified in other ways. For one thing, even from such simple data it is clear, as Tomlinson has elaborated further, that in proportionate terms health expenditure dipped after the early years of the NHS, not recovering until the mid-1960s. ${ }^{35}$ Moreover, as Webster has remarked of the 1950s:

The meagre resources normally available for expansion were for the most part swallowed up in unavoidable expenditure beyond the control of NHS authorities, such as increases in pharmaceutical costs, in remuneration of doctors and dentists, and unanticipated emergencies. ${ }^{36}$

To expand briefly on these points, Tomlinson has shown that in the hospital sector capital expenditure actually fell as a proportion of total expenditure between the late 1930s and the early 1950s. ${ }^{37}$ This, of course, accounts for the lack of hospital building in the early years of the NHS, and for Webster's point about salaries noted above. Pharmaceuticals too proved problematic in that the increasing availability of new, effective, and often expensive drugs had profound cost implications. As Tony Cutler has remarked, during the planning stages of the NHS it was assumed that pharmaceutical expenditure would be around 20 per cent that of general practitioners' remuneration, but by the

\footnotetext{
${ }^{33}$ Jim Tomlinson, 'Why so austere? The British welfare state of the 1940s', J. Soc. Policy, 1998, 27 (1): 63-77.

${ }^{34}$ For a brief commentary on the health centres issue, see Charles Webster, 'Conservatives and consensus: the politics of the National Health Service, 1951-1964', in Ann Oakley and A Susan Williams
} 
late 1950 s the former actually exceeded the latter. ${ }^{38}$ The complex relationship between the pharmaceutical industry, the $\mathrm{MOH}$ and the MRC, which was associated with this rise in pharmaceutical expenditure, has been analysed by Viviane Quirke in relation to corticosteroid drugs, which were developed in the 1950s and 1960s. ${ }^{39}$

Indeed, even before the second post-war Labour government had left office, breaches had been made in the principle of a free service as a result of concerns over apparently spiralling costs. Prescription, ophthalmic, and dental charges were less important in themselves at this stage-although they became the subject of endless political bartering-but rather more so in signalling political and Treasury concern over the apparently limitless expenditure a socialized health service might entail. One famous indicator of such concerns was the appointment, by the Conservative government, of the Guillebaud Committee, which reported in 1956. This, in fact, backfired on the government in that the Committee demonstrated that the NHS was value for money and, indeed, in need of large-scale capital expenditure. ${ }^{40}$

But the setting up of the Guillebaud Committee was indicative of a deep-rooted political and Treasury scepticism about social welfare expenditure. Tomlinson has suggested that the creation of an "austere" welfare state in the 1940s was to have an "enduring legacy in postwar Britain", not least because of the ongoing influence of the Treasury view. ${ }^{41}$ Cutler has argued, in his analysis of the costings carried out during NHS planning, that "early estimates of the likely cost of the NHS played a significant role in providing a questionable standard by which parsimony was regularly justified in the first decade of the Service". ${ }^{42}$ Often crude estimates were, in other words, taken as accurate predictions and so gave those concerned with NHS costs an argument for expenditure restraint. Reminding us that the NHS was born into a wider and troubled world, Daniel Fox has noted that in the late 1940s the United States-at this point still supplying Marshall Aid-put pressure on the British government to cut social welfare expenditure and that at least some British civil servants and politicians agreed with the American analysis. $^{43}$

Webster, as we have seen, has also been critical of the level of government commitment to the NHS in the 1950s, further commenting that resources were denied in areassuch as "medical advance"-where investment was needed to "keep up with rising expectations and the pace of improvement experienced elsewhere in the Western world". 44 Paul Johnson likewise has remarked that although health expenditure did indeed rise inexorably over the period with which we are concerned, none the less this has "not been sufficient to meet rising demand caused by the ageing of the population, the development of new and expensive medical interventions, and higher expectations of treatment and service". ${ }^{45}$ We therefore again need to qualify our optimistic picture

\footnotetext{
${ }^{38}$ Tony Cutler, 'Dangerous yardstick? Early cost estimates and the politics of financial management in the first decade of the National Health Service', Med. Hist., 2003, 47 (2): 217-38, at p. 231.

${ }^{39}$ Quirke, op. cit., note 8 above; idem, 'Making British cortisone: Glaxo and the development of corticosteroid drugs in Britain in the 1950s and 1960s', Stud. Hist. Philos. Biolog. Biomed. Sci., 2005, 36: 645-74.

${ }^{40}$ Webster, op. cit., note 1 above, pp. 204-14.
}

\footnotetext{
${ }^{41}$ Tomlinson, op. cit., note 35 above, p. 75 .

${ }^{42}$ Cutler, op. cit., note 38 above, p. 238.

${ }^{43}$ Daniel M Fox, 'The administration of the Marshall Plan and British health policy', J. Policy Hist., 2004, 16 (3): pp. 191-211.

${ }^{44}$ Webster, op. cit., note 2 above, p. 35.

${ }^{45}$ Paul Johnson, 'The welfare state, income and living standards', in Roderick Floud and Paul Johnson (eds), The Cambridge economic history of modern
} 


\section{John Stewart}

of NHS expenditure in the post-war era to take account of changing demographic patterns and scientific advance. It can thus be argued that increased expenditure was barely keeping pace with changing circumstances.

Even so, it is undeniable that health expenditure did increase significantly in the 1960s. This was due to the Hospital Plan, but here too the picture is more complicated than simply belated recognition of the need for more and more up-to-date hospital facilities, and the provision of capital resources to this end. ${ }^{46}$ For one thing, the Plan was concerned as much with saving money through more efficient use of resources as with expanding services. As such, it was a "failure", characterized by spiralling costs and its eventual replacement, in the early 1970s, by administrative reorganization as the means of promoting economic efficiency. For present purposes, though, what was important about the Hospital Plan was its underlying philosophy. This consisted of, essentially, a technocratic approach which strongly favoured curative, and consequently also hospital-based, medicine. In new, and very large, hospitals heroic surgery and newly synthesized drugs were to be the solution to individual and national health problems. This in turn reflected two key inter-related characteristics of the NHS: the service's administrative structures and the power of the medical profession, and it is to these together, the second of our broad constraining factors, that I now turn.

\section{Constraints: Structures and Attitudes}

From at least the Edwardian era, reformers had argued for a unified health service. In such a service all its components-primary care, hospital care, public health-would be fully integrated and co-ordinated. Such an approach was often combined with a consciously preventive or public health agenda, the idea being that a unified service, deeply embedded in the local community, would be an important way of tackling the causes of ill-health and thereby effecting what was seen as the necessary shift from curative to preventive medicine. However, the NHS as actually brought into being had a tripartite structure: the hospital service; primary care; and, residually, various public health and other duties left in the hands of the local authorities. This clumsy arrangement, which plagued the NHS from its inception down to the 1970s and beyond, had among its drawbacks that the three parts of the service did not necessarily, at local or regional level, have the same geographical boundaries. This was hardly conducive to intra-service co-ordination and integration. The reasons for this tripartite system are complex, but for present purposes I will concentrate on the following. ${ }^{47}$

Britain. Volume III: Structural change and growth, 1939-2000, Cambridge University Press, 2004, pp. 213-37, at p. 235 .

${ }^{46}$ For recent discussions of the Hospital Plan, see John Mohan, Planning, markets and hospitals, London, Routledge, 2002, chs. 6 and 7; John Welshman, 'Hospital provision, resource allocation, and the early National Health Service: the Sheffield Regional Hospital Board, 1947-1974', in Margaret Pelling and Scott Mandelbrote (eds), The practice of reform in health, medicine, and science, 1500-2000: essays for Charles Webster, Aldershot, Ashgate, 2005, pp. 279-301; and John Stewart, 'Hospitals, regions, and central authority: issues in Scottish hospital planning, 1947-1974', in ibid., pp. 263-78.

${ }^{47}$ For one analysis of why the NHS took the form it did, see John Stewart, 'Ideology and process in the creation of the British National Health Service',

J. Policy Hist., 2002, 14 (2): 113-34. 
First, Bevan, when formulating the NHS, was relatively uninterested in the administrative details. He was therefore prepared to cede significant power in the running of the service to the medical profession, both organizationally and in terms of strategic thinking. One area where Bevan was interested in administrative structures, however, was in his hostility to any idea of local authorities being principally responsible for the running of the new service. The latter was thus, by previous standards of British social administration and in contrast to most European systems, highly centralized.

Second, the medical profession undoubtedly gained a significant medico-political victory in the 1940s through the ceding to it of strategic and administrative powers. But much of the profession itself was at this stage at best indifferent, at worst actively hostile, to preventive medicine, social medicine, and public health. A further reason for the "failure" of health centres-institutions which, as we have seen, were actively to address matters such as the promotion of health-was the lack of professional commitment to them. As its critics rather cynically remarked in the 1930s and 1940s, the medical profession had a "vested interest" in ill-health. ${ }^{48}$

Third, and leading on from the two previous points, the administrative structures of the NHS both allowed for and encouraged a situation wherein hospitals and hospital medicine came to dominate health service strategy, just as the leaders of the medical profession desired. In fact this was to become a source of grievance to general practitioners who felt their role was being diminished. From the point of view of this essay, what is perhaps more important is that a service was created which favoured central rather than local control; curative over preventive and social medicine and public health; and hospitals over health centres and, indeed, primary care in general.

Moreover there was a further economic dimension to this in that the non-curative aspects of the service were squeezed between the perceived need, led by the Treasury, to keep costs down and the large sums involved in the technocratic approach as manifested by, for example, the Hospital Plan. The location of many actually or potentially preventive services in the local authority sector-a sector accorded low status-did little to help. In short, the non-curative parts of the NHS have always been second best. The career of social medicine, which started off with high hopes but soon narrowed in focus and declined in influence, is illustrative of this broader history. ${ }^{49}$ Against this background it is salutary to note that the general improvement in health conditions mentioned earlier notwithstanding, health inequalities persisted in British society from the founding of the NHS to the 1970s and beyond. Such inequalities continue, moreover, to be strongly related to social class and geography. ${ }^{50}$ The Resource Allocation Working Party, set up in 1975, was a somewhat belated attempt to address this issue. ${ }^{51}$

\footnotetext{
${ }^{48}$ For numerous instances of this sort of language, see Stewart, op. cit., note 4 above.

${ }^{49}$ On which, see Porter, op. cit., note 5 above.

${ }^{50}$ Simon Szreter, 'Health, class, place and politics: social capital and collective provision in Britain', in Virginia Berridge and Stuart Blume (eds), Poor health: social inequality before and after the
}

Black Report, London, Frank Cass, 2003, pp. 27-57. See also the other essays in this volume.

${ }^{51}$ For a brief account of the Working Party, its methodology and findings, see Christopher Ham, Health policy in Britain: the politics and organisation of the National Health Service, 3rd ed., Basingstoke, Macmillan, 1992, pp. 194-8. 


\section{John Stewart}

\section{Constraints: The Wider Context}

Our third broad constraint on the NHS in the quarter century after its creation concerns the wider context in which it operated. Despite its popularity, judging the service's status and performance is problematic. To return to international comparisons, it is noticeable that in the era of the "classic" welfare state Britain's expenditure on welfare was overtaken not only by West Germany but also by France, Denmark, Sweden, Italy, and the Netherlands in the 1950s; and in the early 1970s by Norway and Finland. Focusing on health, if we take the early 1990s and compare Britain with other OECD countries, then roughly speaking the picture which emerges is that the British health care system is neither extravagant nor parsimonious. Similarly, while for the most part a stateprovided service, Britain once again is not at the extreme statist end of this spectrum. In terms of outcomes, here too the British experience is not dissimilar to that of other western European nations, for example in terms of life expectancy. ${ }^{52}$ At least on these rather crude criteria, therefore, it is difficult to make a case for NHS exceptionalism or for a service which is in the vanguard of health promotion.

On the domestic front, it might be assumed that the government department responsible for the central institution of the welfare state, the Ministry of Health, would be at the forefront of British politics. In fact, this was not always the case. For significant parts of our period, the Minister of Health was not a member of the Cabinet, and indeed in the 1950s in particular the post was subject to rapid turnover and on occasions filled by individuals not of the most inspiring or dynamic type. ${ }^{53}$ Although this situation improved in the late 1960s, it was also complicated by the absorption of the health ministry into the huge Department of Health and Social Security, an arrangement which persisted until the late 1980s. In a revealing insight into the attitude of both the medical profession and the problems of running such an organization Richard Crossman recorded that:

When an administrator has a job to do for the Secretary of State, he puts everything else aside and does it as the first priority. But not a doctor. They feel totally aloof and I increasingly find that their part of the [merged] Department runs on its own and doesn't like even to feel that it is being ordered about by the Secretary of State. ${ }^{54}$

Lacking a place in Cabinet was not merely a status issue, nor are we simply comparing the charismatic Bevan with some of his less colourful successors. Absence from the Cabinet meant that the Minister of Health had a much more difficult task in negotiating with the ever parsimonious Treasury for funds. It is notable that one of the few ministers of health to make any significant impact in the 1950s and early 1960s was Enoch Powell, the author of the Hospital Plan. Powell had the support of the Treasury precisely because of his proto-monetarist views, and his time at the Ministry is remembered as much for his determination to cut expenditure as for the undoubtedly innovative, if ultimately flawed, Hospital Plan. Generally speaking, though, ministers of health had a tough

\footnotetext{
${ }^{52}$ José Harris, 'Enterprise and welfare states: a comparative perspective', Trans. R. Hist. Soc., Fifth Series, 1990, 40: 175-95, at p. 180; Martin Powell, Evaluating the National Health Service, Buckingham, Open University Press, 1997, pp. 150-64.
}

\footnotetext{
${ }^{53}$ Webster, op. cit., note 2 above, p. 35.

${ }^{54}$ Richard Crossman, The diaries of a cabinet minister. Volume 3: Secretary of State for Social Services, 1968-70, London, Hamish Hamilton and Jonathan Cape, 1977, p. 812.
} 
time financially. This situation was exacerbated in that the Ministry's perceived status led in turn to its recruiting poorer quality civil servants. It was thus something of a civil service backwater and this is borne out by comparison with the legally and administratively separate Scottish health service. Scotland's NHS chief was the Secretary of State for Scotland, who sat in the Cabinet; and the relevant Department of the Scottish Office recruited civil servants of a markedly higher calibre than those of the Ministry of Health. Whether by accident or design this resulted in a more integrated and co-ordinated service which also managed to extract more expenditure per capita from the Treasury. ${ }^{55}$

Furthermore, and notions of post-war "consensus" notwithstanding, the creation and development of the NHS was a highly contested process. ${ }^{56}$ So, for example, the Conservative government, in private at least, did little to hide its annoyance at the Guillebaud Report. ${ }^{57}$ Even before Guillebaud, two future Conservative health ministers were raising concerns about the provision of a "free" health service on a non-contributory basis and about the validity of Beveridge's "assumption" of the need for such a service in his wartime report on social insurance. ${ }^{58}$ Nor were differences over health policy simply between the political parties. In 1968 Richard Crossman recorded an acrimonious meeting of the Parliamentary Labour Party over the issue of prescription charges. This was, he remarked, "the worst we have ever had". What was taking place was "a demonstration of conscience after the conscience had already been raped". 59 The history of the National Health Service is thus both shaped by, and contributor to, broader socio-economic and political circumstances. As commentators have variously pointed out, the NHS has since its inception appeared to exist in an almost permanent state of "crisis", real or imagined. ${ }^{60}$ This can be seen as a reflection of the insecurities of post-war Britain, even during the "golden age" of the welfare state.

\section{Constraints on the MRC}

The MRC too was subject to constraints, as part of the broader political and socioeconomic landscape. In the mid-1950s one of its major projects was clinical trials of influenza vaccine. To carry out this research, the voluntary co-operation of various individuals and bodies was required. On one level, this was a success. As a letter from the Public Health Laboratory Service noted in 1955, the unprecedentedly widescale "cooperative effort" involved had "given us the most valuable results ... and has ... added

\footnotetext{
${ }^{55}$ John Stewart, 'The National Health Service in Scotland, 1947-1974: Scottish or British?', Hist. Res., 2003, 76 (193): 389-410; idem, op. cit., note 46 above.

${ }^{56}$ Charles Webster, 'Conflict and consensus: explaining the British Health Service', 20 Century $\mathrm{Br}$. Hist., 1990, 1 (2): 115-51.

${ }^{57}$ Webster, op. cit., note 2 above, p. 32.

${ }^{58}$ Iain Macleod and J Enoch Powell, The social services: needs and means, 2nd ed., London, Conservative Political Centre, 1954, pp. 12-13; see also Webster, op. cit., note 2 above, p. 36.
}

\footnotetext{
${ }^{59}$ Richard Crossman, The diaries of a cabinet minister. Volume 2: Lord President of the Council and Leader of the Commons, 1966-68, London, Hamish Hamilton and Jonathan Cape, 1976, pp. 707-8.

${ }^{60}$ See, for example, the discussion in Julian Le Grand and Polly Vizard, 'The National Health Service: crisis, change, or continuity?', in Howard Glennerster and John Hills (eds), The state of welfare: the economics of social spending, 2nd ed., Oxford University Press, 1998, pp. 75-121.
} 


\section{John Stewart}

to our knowledge of the epidemiology of influenza". ${ }^{61}$ But the co-operating bodies, like the MRC itself, were bound by the economic circumstances of the times. Professor Alexander Macdonald of the University of Aberdeen, for instance, wrote that his department was happy to participate in the MRC trials. However his university's "dire financial straits" made it difficult to purchase even the most basic materials, in this particular case fertile eggs. ${ }^{62}$

Relating more directly to the Council itself, in 1961 a question on its future was put to the Commons by Laurie Pavitt MP. Pavitt, at this point Chair of Labour's Health Group and later a member of the MRC, asked what the prospects were for improving medical research. In a positive response, the Parliamentary Secretary to the Ministry of Science pointed out that expenditure on the Council had trebled over the preceding ten years. Pavitt found this "totally unsatisfactory". Was the Parliamentary Secretary aware, he continued, "that the United States are now spending about 4,000 million dollars on research? Is he aware that this is costing the country quite a lot in its bills for imported pharmaceutical products?" The former replied that medical research was in fact carried out by a range of bodies, to which Pavitt further suggested that the government "arrange for some planning and co-ordination instead of having this ramshackle arrangement for research". 63

This was a revealing exchange on a number of levels. The concern over pharmaceuticals, for example, further attests to the rapid post-war expansion in this field and the associated demands on the NHS. ${ }^{64}$ Others picked up similar points. Landsborough Thomson claimed that in the mid-1960s the US government's medical and health research expenditure was around five times that of its British counterpart on a per capita basis. ${ }^{65} \mathrm{He}$, like Pavitt, also pointed to the dispersed and relatively unco-ordinated nature of medical research, with the MRC, the universities, the hospitals, charitable foundations, and private industry all pursuing their own agenda. ${ }^{66}$ On the issue of universities, and displaying the MRC's limitations in terms of directing and co-ordinating research, the Council told the Royal Commission on Medical Education that arrangements for research to be taken over by universities were "dependent entirely on the willingness of the university to accept continuing responsibility for it: there was no question of foisting research on unwilling universities". ${ }^{67}$

Pickering, in his 1963 speech, likewise compared British medical research expenditure unfavourably with that in America, one consequence of which was the "loss of scientists abroad". ${ }^{68} \mathrm{He}$ was thus adding to broader fears about the "brain drain" which, so the

\footnotetext{
${ }^{61}$ National Archives of Scotland (hereafter, NAS), HH 101/2895, circular letter to medical profession, 29 April 1955, from the Public Health Laboratory Service.

${ }^{62}$ NAS, HH 101/2895, letter, 19 Oct. 1956, Professor Alexander Macdonald, University of Aberdeen, to Dr Sutherland, Department of Health for Scotland.

${ }^{63}$ Parliamentary Debates, 5th Series, vol. 644, cols. 1043-44, Oral Answers, 18 July 1961.

${ }^{64}$ For one example of this trend, see Viviane Quirke, 'Putting theory into practice: James Black,
}

receptor theory and the development of the betablockers at ICI, 1958-1978', Med. Hist., 2006, 50 (1): 69-92.

${ }^{65}$ Landsborough Thomson, Half a century of medical research. Volume 1, op. cit., note 9 above, p. 204.

${ }^{66}$ Ibid., p. 191

${ }^{67}$ NAS, COM 5/201, Royal Commission on Medical Education, 'Summary of Discussion on 9/3/67 with Representatives of the Medical Research Council'.

${ }^{68}$ Pickering, op. cit., note 30 above, p. 1294. 
argument went, was contributing to relative economic decline. The supply of scientific labour was not, however, a new issue. A Treasury official reported in 1954 that it was the MRC's view that "the real bottleneck in medical research is the number of people of really good quality whom they can get". Putting a typical Treasury spin on this view, the official thus further remarked that the "limitation is brains rather than money". 69

In his "official" history Landsborough Thomson, in a carefully constructed passage, agreed that it was "broadly true" that skilled scientists rather than financial resources had been the "major limiting factor" in the MRC's development. None the less, he attacked as "naïve" the idea that funds should be "allocated on the basis of the relative importance of various diseases". Leading directly on from this, he remarked that funding had "never been lavish in relation to demand" and that there had thus been a constant need for "economy in expenditure". Such financial stringency was, of course, in general terms necessary but could also have a "retarding effect". The Council was therefore put in the (implicitly impossible) position of having to balance existing projects with new ones. Consequently,

... however substantial the Council's funds have been in recent times, there remains a constant difficulty in preserving a sufficient margin for exploiting the new opportunities that arise in unforeseen ways and often with heavy financial implications; yet it is developments of this kind that merit special priority. ${ }^{70}$

To put a complicated argument crudely, by its very nature scientific investigation was unpredictable and could follow both fruitful and unfruitful paths. But until those paths were followed, nobody could be sure what lay at their ends. Investment in scientific research should not, therefore, be so inflexible that it unreasonably curtailed such journeys, present or future. In certain respects, this is strikingly parallel to the argument for preventive medicine-invest now for long-term rather than immediate gains.

The MRC was again discussed in Parliament in the early 1970s. The issue this time was the deliberations of the Rothschild Committee, which had been asked to look at various aspects of the machinery of government. Labour MPs were clearly concerned about proposals which, as they saw it, would hamper the MRC's object of "pursuing an independent policy for the advancement of knowledge towards the relief of human suffering". One way in which this might happen was through the introduction of "the customer-contractor principle in relation to applied medical research" - an unwitting anticipation of what was to be a central aspect of health service policy in the 1980s and 1990s. Margaret Thatcher, responding in her capacity as Secretary of State for Education and Science, articulated the government's position that "the customer/ contractor principle should be implemented in respect of applied research and development carried out or sponsored by the Government whether by the research councils or elsewhere". 71

\footnotetext{
${ }^{69}$ Quoted in Landsborough Thomson, Half a century of medical research. Volume 1, op. cit., note 9 above, p. 202.
}

\footnotetext{
${ }^{70}$ Ibid., pp. 188-9.

${ }^{71}$ Parliamentary Debates, 5th Series, vol. 828, cols. 323-5, Written Answers, 21 Dec. 1971.
} 


\section{John Stewart}

Finally, in this section I turn to the report of a Joint Working Party, under the chairmanship of Sir Douglas Black, produced at the time of health service re-organization in the mid-1970s. This re-visited the issue of clinical research and the proposal that where appropriate this be devolved to regional and local bodies. We saw earlier that this was the aim of the 1953 MRC report which had also adopted a very broad definition of what constituted "clinical research". The Joint Working Party noted that the recommendations of the 1953 report for decentralized clinical research had been put in place in $1958 / 59$. At this point, only a handful of regional bodies had availed themselves of the opportunity to gain funds from the MRC and in consequence there was an underspend on even the modest financial estimate. Although by the early 1970s take up was much greater, with $£ 1.2$ million being expended, none the less when shared among the various regional bodies each gained a relatively small amount. The Working Party made a virtue of this, noting that "the scheme was intended for relatively modest short-term work, major research programmes being reserved for the central organisation". More problematically in the early years, despite the original emphasis on "the importance of field studies and observations amongst the general population", resources had been used "entirely to the support of research in hospitals". The Chief Medical Officer had sought to address this through a series of initiatives in the mid-1960s, but "most Boards still continued to spend the great majority of funds allocated ... in support of hospital projects". As in the health service more generally, then, the primary focus appears to have been on hospitals. The Joint Working Party not only recommended, therefore, that more funds be allocated to the scheme, but also reaffirmed that "the scheme is designed to support a wide range of research in the community as well as in hospital". It should thus be re-named "and be publicised widely amongst the health professionals in all parts of the service". 72

What is of concern for present purposes is not the detail of these cases but rather the more general point that the MRC, just like the NHS, operated in changing historical circumstances and that political and socio-economic concerns impacted on this "independent" body just as much as on any other. Nor, as we have seen, was medical research unified. Besides the MRC, other interested parties, with their own agenda, included the universities and private companies. The former also, of course, had to deal with other health-related agencies and departments. All this is brought out clearly in Webster's much-cited article on the NHS and tobacco smoking. Early in the postwar period the MRC had played an important role in supporting research into smoking and health, and promoting its findings. However, partly because of the vested interests in tobacco consumption; partly because of political fears about revenue loss should smoking be curtailed; partly because of disputes about the reliability of the evidence; and partly because of the complex and fragmented structures of the NHS, the "scientific" findings supported by the MRC took a long time to translate into policy. As Webster has remarked of the fourth of these points, a "powerful and complex advisory machinery stood between MRC and the NHS" which did little to "facilitate swift action

\footnotetext{
${ }^{72}$ Department of Health and Social Security, Welsh Office, and Medical Research Council, Report of the Joint Working Party on the Decentralised
}

Clinical Research Scheme in England and Wales, London, HMSO, 1974, pp. 3-5, 24. 
The Political Economy of the NHS, 1945-1975

on an important issue". ${ }^{73}$ Virginia Berridge likewise has drawn attention to the problems of implementing policy hostile to smoking, and indeed the somewhat ambiguous attitude of the MRC at certain key points in the debates over smoking bears out this analysis. $^{74}$

\section{Conclusion}

Rodney Lowe has observed that the "establishment of the NHS in 1948 ... provided an opportunity to demonstrate the superiority of collective action and public initiative. This opportunity was not fully seized." Lowe has attributed this "failure" in part to the attitudes of the medical profession and to the service's structures. ${ }^{75}$ We have seen how these did indeed inhibit the development of a fully socialized service which took as its model of health not simply the absence of sickness but also the active promotion of physical and mental well-being. Lowe's judgement is therefore harsh, but fair, particularly when we also take into account the relationship between health expenditure and factors such as changing population structure. In our case study of the MRC, meanwhile, we have seen that concerns were variously expressed about the level of resources allocated to it and its place in the complex bureaucratic structures of the modern state. The Council's ambitions for a broadly-based form of medical research, embracing the clinical and the social, have to be seen against this background of constraints and change. Further research is clearly necessary on the Council's post-war history, but the interpretation presented here suggests both the organization's positive achievements and its need to operate in an environment which on occasion inhibited its aspirations.

Of course it can quite legitimately be argued that the demand for health care, and for support for scientific research, is essentially incapable of ever being satisfied. And it is clear that while the early NHS did at least acknowledge the need for a preventive programme, it was taken aback by the demands on its curative services which the advent of "free" health care engendered. However, pursuing a social/preventive/public health agenda would have required a much more radical approach than that adopted in the post-war era. Attacking health inequalities would, by the same token, have downgraded the role of biomedicine in favour of more obviously environmental approaches, although of course the two are not necessarily mutually exclusive. What is also problematic, and this is a dilemma of long-term planning in a democratic society, is that addressing health issues from a preventive standpoint involves not only political will, but also a recognition that its benefits may take a considerable time to come to fruition. To put it another way, it is politically more attractive to increase short-term hospital capacity than to institute a preventive programme via, say, health centres.

It can, however, equally be argued that some of the interest groups and organizations discussed in this volume stood to benefit from the sort of situation described in this

\footnotetext{
${ }^{73}$ Charles Webster, 'Tobacco smoking addiction: a challenge to the National Health Service', $B r . J$. Addiction, 1984, 79 (1): 7-16, at p. 15 and passim.

${ }^{74}$ Virginia Berridge, 'Post-war smoking policy in the UK and the redefinition of public health', 20 Century Br. Hist., 2003, 14 (1): 61-82, at p. 64ff and
}

passim. See also Timmermann, op. cit, note 29 above, passim.

${ }^{75}$ Rodney Lowe, The welfare state in Britain since 1945, Basingstoke, 3rd ed., Palgrave Macmillan, 2005, pp. 201-2. 


\section{John Stewart}

essay. For them, hospital-based medicine, a broadly curative philosophy, and a "mixed economy of research" could clearly offer significant opportunities. All this suggests is that, when discussing the sort of processes and organizations dealt with in the other essays in this volume, we need to be conscious of the political economy of socialized health care and the differing aims and aspirations of the various parties involved in the provision of health care and medical research since the Second World War. 